\title{
Micropolítica do terreno: família, espaço e reprodução social no Litoral do Piauí
}

Francisco Raphael Cruz Maurício ${ }^{1}$ Universidade Federal do Piauí

Resumo: Neste artigo, argumento que a cerca e o parentesco produzem, por um lado, divisa espacial entre vizinhos e, por outro lado, unidade social entre parentes no povoado Pedra do Sal, localizado no litoral piauiense. Através da cerca e do parentesco, a família busca garantir sua reprodução social espacialmente referenciada num contexto de escassez de "terreno". As práticas de reservar, vender, pedir, tomar e retomar "terreno" compõem o que chamarei de micropolítica do terreno, isto é, o manejo do conflito e da solidariedade entre parente, vizinho e amigo em torno da apropriação do espaço.

Palavras-chave: comunidades tradicionais; família; vizinhança.

${ }^{1}$ Professor substituto do Departamento de Ciências Sociais da Universidade Federal do Piaú. Doutor e mestre em Sociologia pela Universidade Federal do Ceará. Graduado em Ciências Sociais pela Universidade do Estado do Rio Grande do Norte. 


\title{
Micropolítica de lo terreno: familia, espacio y reproducción social en el litoral de Piauí
}

\begin{abstract}
Resumen: En este artículo, sostengo que la "cerca” y el parentesco producen, por un lado, una frontera espacial entre vecinos y, por otro, una unidad social entre parientes en el pueblo de Pedra do Sal, situado en la costa de Piaui. A través de la cerca y el parentesco, la familia busca garantizar su reproducción social espacialmente referida en un contexto de escasez de "terreno". Las prácticas de reservar, vender, pedir, tomar y recuperar "terreno" constituyen lo que llamaré la micropolítica de lo terreno, es decir, la gestión de los conflictos y la solidaridad entre pariente, vecino y amigo en torno a la apropiación del espacio.
\end{abstract}

Palabras clave: comunidades tradicionales; familia; vecindario.

\section{Micropolitics of the terreno: family, space and social reproduction on the Piauí Coast}

\begin{abstract}
Summary: In this article, I argue that the "cerca" and the kinship produce on the one hand, spatial border between neighbors and on the other hand, social unity between relatives in the village Pedra do Sal, located on the coast of Piaui. Through the cerca and the kinship, the family seeks to ensure its social reproduction spatially referenced in a context of scarcity of "terreno". The practices of reserving, selling, asking for, taking and retaking "terreno" make up what I will call the micropolitics of terreno, that is, the management of conflict and solidarity among relative, neighbor and friend around the appropriation of space.
\end{abstract}

Keywords: traditional communities; family; neighborhood. 
$\mathrm{F}$ lamílias de pescadores, agricultores e artesãos construíram, ao longo do tempo, um modo de habitar a parte rochosa do litoral piauiense chamada de Pedra do Sal. Elas estabeleceram um "povoado" entre a rocha da praia e a lama do mangue por meio da combinação do uso comum da "terra" e da posse familiar do "terreno", além de instituírem uma "comunidade" pela partilha de uma memória social e de um pertencimento local. A ocupação do referido lugar ocorreu desde, pelo menos, 1826 (MAURÍCIO, 2020) e está associada ao estabelecimento no litoral do Piauí de núcleos de pescadores, agricultores e fazendeiros (CASTELLO BRANCO FILHO, 1982).

Os "moradores" da Pedra do Sal utilizam duas categorias de classificação do território: "terra" e "terreno". A "terra" engloba lugares de uso comum como praia, mangue e mata, destinados ao "trabalho", onde se realiza o extrativismo artesanal de recursos vegetais e animais importantes na economia das famílias. Já o "terreno" engloba a casa e suas extensões como o quintal e o sítio, lugar de residência, mas também de trabalho, notadamente a agricultura familiar e a criação de animais de pequeno porte.

O terreno é onde a família nuclear ou extensa reside e organiza a vida doméstica por meio de rituais como refeição, repouso e celebração. É no terreno que os parentes próximos (pai, mãe, filhos e netos) convivem a maior parte da vida e onde os parentes distantes (tios e primos) são recebidos em "visitas". O costume local prescreve que, após o casamento, os pais cedam parte do terreno ao filho ou filha. Este ou esta, por sua vez, constrói uma casa, e, por conseguinte, inicia nova família nuclear próxima à casa dos pais. Os casamentos são exogâmicos e a residência não obedece a uma regra exclusiva de patrilocalidade ou matrilocalidade. O casamento dos filhos permite a passagem da família nuclear para a família extensa e a inclusão no terreno de parentes não apenas consanguíneos, mas também de parentes por afinidade.

Os moradores do lugar utilizam cerca de madeira e arame para dividir os terrenos de diferentes famílias. Entre a casa do pai e a do filho, pode apresentar-se cerca, mas esta é acompanhada de portão, o que possibilita o fluxo de parente entre as casas. Tal portão não se encontra entre as cercas de diferentes famílias, não permitindo, assim, o trânsito de vizinho entre "terrenos". A cerca é utilizada para estabelecer a divisão espacial entre terrenos e a unidade social entre parentes. Unir e dividir constituem a dialética da cerca na Pedra do Sal.

Nos anos 2000, "gente de fora"2 foi atraída para o lugar em decorrência da instalação de parques geradores de energia eólica e do anúncio da construção de resorts de luxo. Eles adquiriram "terrenos" através da compra de parte da posse de moradores ou da ocupação de áreas próximas à praia. Essa "invasão" tirou o "sossego" dos moradores, gerou especulação imobiliária e escassez de terreno para os nativos que retornavam ao lugar após migração por motivos de trabalho. A família que "vendeu terreno" para "gente de fora" dificultou que o filho que migrou se reestabelecesse no lugar, pois não havia espaço suficiente para mais uma família conjugal. Aquela que não vendeu terreno, garantiu uma reserva de espaço para ser transmitida ao filho após o casamento, assegurando, assim, seu reestabelecimento no povoado.

${ }^{2}$ Categoria que designa pessoa não nascida no povoado ou que não possui parentela no lugar, como os turistas que visitam a praia nos fins de semana ou os parnaibanos, teresinenses, brasilienses que adquiriram "terreno" na Pedra do Sal. 
A família que assegurou a reserva não cede terreno para vizinho que vendeu ou à amigo que deseja se estabelecer no povoado, pois, assim, compromete a reprodução social da família no lugar. Passa a ocorrer na Pedra do Sal o assédio de família que vendeu sobre a que reservou espaço para a próxima geração. No contexto de escassez de terreno, o grupo familiar reforça a cerca como divisa espacial entre vizinhos que promove unidade social entre parentes, garantindo a centripetalidade sociológica (SIMMEL, 2013) do grupo familiar (conjugal ou extenso) no "terreno". O que está em jogo para o habitante da parte rochosa do litoral piauiense é que a cerca continue funcionando como aquilo que emoldura fisicamente uma unidade interativa (SIMMEL, 2013), isto é, a família, e que esta, por sua vez, emoldure simbolicamente o "terreno" por meio das relações de parentesco.

Neste artigo, argumento que a cerca e o parentesco produzem, por um lado, divisa entre vizinhos e, por outro, unidade entre parentes. Encaro a cerca e o parentesco como mecanismos que se reforçam mutuamente e através dos quais a família busca garantir sua reprodução social espacialmente referenciada num contexto de escassez de "terreno". As práticas de reservar, vender, pedir, tomar e retomar terreno são os objetos de estudo deste artigo e compõem o que chamarei de micropolítica do terreno, isto é, o manejo do conflito e da solidariedade entre parentes, vizinhos e amigos em torno do espaço. Esta reflexão localiza-se no campo de estudo das estratégias de reprodução social do campesinato e das populações tradicionais, com ênfase nos aspectos espaciais. Os dados empíricos provêm do trabalho de campo realizado na Pedra do Sal entre os anos de 2015 e 2019 e foram refletidos à luz de estudos da antropologia rural sobre a reprodução social camponesa (COMERFORD, 2003; GODÓI, 1999; MOURA, 1978; WOORTMANN, 1995) e de aportes da sociologia do espaço (DURKHEIM, 1978; SIMMEL, 2013) como moldura, divisão e diferenciação.

Inicio o artigo apresentando ao leitor algo da morfologia social do lugar (MAUSS, 1972) e da cosmografia (LITTLE, 2004) e história de seus habitantes (MAURÍCIO, 2020). Em seguida, apresento três situações que envolvem tensão social entre parente, vizinho e amigos que queriam se tornar vizinhos. É nesta parte do texto que descrevo as práticas de reservar, vender, pedir, tomar e retomar terreno como componentes da assim chamada micropolítica do terreno. Finalizo destacando, de modo breve, alguns estudos de antropologia rural sobre a relação entre parentesco e território, assim como as contribuições da sociologia do espaço para pensar a estratégia de reprodução social espacialmente referenciada das famílias pedral. Concluo que o bom manejo das relações de conflito e solidariedade entre parentes, vizinhos e amigos preserva o "terreno" como espaço de reprodução social das famílias, pois evita a migração de parentes e garante a centripetalidade sociológica da família no terreno.

\section{Breve história e cosmografia de um "povo" à beira-mar}

A Pedra do Sal situa-se no litoral de Ilha Grande de Santa Isabel, um bairro rural do município de Parnaíba e uma ilha marinha costeira e oceânica de 240 $\mathrm{km}^{2}$ (COMISSÃO ILHA ATIVA, 2012). Em 288 hectares, estão alocados os aparelhos públicos de saúde e educação, a associação de moradores e o cemitério comunitário, a capela Bom Jesus dos Navegantes e a Assembleia de Deus, bares, quitandas e aproximadamente 350 casas pertencentes aos "moradores" da Pedra do Sal e à "gente de fora", como os que veraneiam no lugar em datas específicas do calendário nacional como o Carnaval ou o Ano Novo (MAURÍCIO, 2020). A 
Pedral encontra-se distante $16 \mathrm{~km}$ do centro urbano da municipalidade, cujo acesso se dá pela Ponte Simplício Dias da Silva e pela PI-116. É o único povoado de Santa Isabel a encontrar o Oceano Atlântico, possuindo uma faixa de praia com $8 \mathrm{~km}$ de extensão utilizada para a subsistência dos moradores, para o lazer dos turistas e para a geração de energia eólica por empresas multinacionais.

Em 2012, o lugar possuía uma população de 980 habitantes agrupados em 190 famílias, cujos membros eram ativos no extrativismo marinho e florestal, na agricultura familiar, na criação de animais, no comércio de alimentos e bebidas em bares na praia. Uma parcela menor ocupava-se no trabalho doméstico e na construção civil. Em 2015, 80\% dos habitantes do lugar possuíam renda de até 1 salário-mínimo, $96 \%$ possuíam moradia própria - destas, $75 \%$ eram construídas com tijolo e 25\% de taipa. Quanto aos níveis de educação formal, $44 \%$ dos habitantes cursaram o Ensino Fundamental e 36\% o Médio (BEZERRA, 2016; BEZERRA et al., 2017).

Apesar da Pedra do Sal pertencer administrativamente ao município de Parnaíba, estar na Pedral é percebido como estar fora da "cidade", mas dentro da "ilha", sendo comum ouvir dos ilhéus, "vou à Parnaíba". Ir à Parnaíba é ir até o hospital, ao colégio, ao comércio, à rodoviária. Assim, o "povoado" é percebido por seus habitantes como englobado por Ilha Grande de Santa Isabel e não pelo município de Parnaíba, que assume a posição desse outro (lugar), a cidade, na cosmografia (LITTLE, 2004) dos moradores. No vocabulário pedral, "comunidade" é palavra cuja conotação é sociológica, isto é, refere-se ao campo semântico das relações sociais; já "povoado" possui sentido mais geográfico, que por sua vez associa-se ao campo semântico das relações ecológicas. Assim, o termo "comunidade" é utilizado, por exemplo, em histórias sobre a luta por território com fazendeiros no passado ou com empresas de energia eólica no presente. Já o termo "povoado" é mais comumente encontrado em descrições nativas sobre o lugar, sua paisagem de praia, mangue, dunas e matas. Pode-se dizer que a "comunidade" está para o "povoado" assim como a pessoa está para o lugar.

Por lá, "morador" designa quem mora na Pedra do Sal e possui uma parentela residente no povoado. Alguém que lá não nasceu, mas constituiu família e reside, é considerado morador, como os que migraram de povoados vizinhos e estabeleceram família no lugar ou os que se casaram com nativos e iniciaram novas famílias. Aqueles que possuem casa de veraneio ou frequentam a praia nos finais de semana são chamados de "gente de fora", expressão que engloba o turista, o parnaibano, o teresinense ou o paulista, esse outro da cidade. O oposto destes é o "filho do lugar", que designa entre os moradores aqueles que nasceram e se criaram no povoado, denotando, assim, uma imagem de nós configuradora de ordem hierárquica (ELIAS; SCOTSON, 2000) na valorização da origem e da permanência prolongada na Pedra do Sal, elementos sociais e temporais que distinguem, no interior da "comunidade", o "filho do lugar" em relação ao "morador".

Quanto às categorias de classificação do espaço, como já mencionado, existem a "terra" e o "terreno". A palavra terra engloba os lugares de uso comum como a praia, o mague e a mata. Já o terreno identifica aqueles que são de uso familiar como a casa, o quintal e o sítio. Pode-se afirmar que a terra está para o terreno assim como a comunidade está para a família. Enquanto o uso da terra é ordenado por regras consuetudinárias que não estão escritas em parte alguma, mas ordenam as práticas extrativistas em todo o lugar, o terreno é organizado pelas relações de parentesco, notadamente aquelas estabelecidas entre o pai e os filhos, que ordenam a divisão e a sucessão do terreno após o casamento. A territorialidade (GODÓI, 2014) pedral resulta da combinação da posse familiar do "terreno" 
com o uso comunitário da "terra", sendo essas posse e uso ordenadas cada uma por seus respectivos códigos familiar ou comunitário que instituem que qualquer morador pode caçar na mata, mas somente os parentes manejam as galinhas no quintal. Assim, nessa cosmografia, as regras consuetudinárias estão para as relações de parentesco assim como o uso comum da terra está para o uso familiar do terreno.

Durante o século XX e o início do XXI, os moradores da Pedra do Sal viveram sob o mandonismo e o coronelismo da família Silva, composta por políticos e fazendeiros de Parnaíba. Apesar dessa família não ter a posse legal das terras do lugar, só conquistada em 1989, ela controlava o ingresso e a permanência das pessoas no povoado e estabeleceu um sistema de morada (VERÇOZA, 2018) no qual o acesso à terra era retribuído pelo morador com o voto nos candidatos da família Silva nos pleitos políticos piauiense e nacional. Tal sistema perdurou até o início dos anos 2000 e foi progressivamente desarticulado à medida que os moradores se organizaram como sociedade civil em sindicatos e associações nos anos 1990, além da melhora na condição de vida nos anos 2000 por meio do auxílio financeiro proveniente do seguro-defeso ao pescador artesanal e de programas sociais como o Bolsa Família.

Na primeira metade dos anos 2000, os Silva passaram a negociar as terras de Ilha Grande com empresas multinacionais de turismo imobiliário e geração de energia eólica. Os direitos territoriais dos moradores foram invisibilizados nesse processo e, atualmente, parte das terras de uso comum do povo da Pedral encontra-se sob posse das empresas ou sob o impacto ambiental promovido por suas instalações. O fim do mandonismo silvista e o estabelecimento das multinacionais acarretou mudanças no povoado.

A primeira delas foi que a cerca passou a ser utilizada pelos moradores para demarcar o "terreno" familiar, algo que os Silva proibiam, visto que a cerca simbolizaria a posse do morador em detrimento da propriedade dos Silva. A segunda foi que a instalação das empresas atraiu "gente de fora" para a Pedral e esta passou a demarcar terrenos para si e a comprá-los de moradores, alterando a demografia do povoado, gerando especulação imobiliária. A terceira foi que os filhos de moradores que migram para centros urbanos passaram a ter dificuldade em se reestabelecer no povoado, pois a família havia vendido para "gente de fora" parte do "terreno" que eles poderiam ocupar. Essas três mudanças configuraram um novo contexto socioespacial na Pedra do Sal, no qual parte das famílias do lugar experimentou escassez de terrenos e outra parte passou a defender os terrenos reservados para as diferentes gerações da família. É nesse contexto que as práticas de reservar, vender, pedir e retomar "terreno", a seguir analisadas, produziram tensões entre parente, vizinho e amigo, compondo aquilo que chamarei de micropolítica do terreno.

\section{Situação 1 - Reservar ou vender terreno}

A primeira situação que apresento envolve a tensão entre vizinhos em torno das cercas do "terreno" e me foi relatada por Norma, uma artesã e líder comunitária com 46 anos de idade. Ela nasceu no povoado vizinho, Labino, cujo limite espacial com a Pedra do Sal é dado pelas matas de cajueiro. Como outras crianças e adolescentes do lugar, ela migrou e trabalhou de empregada doméstica, mas retornou à casa dos pais e depois se estabeleceu na Pedra do Sal, casando-se com 
um nativo do povoado. Eles tiveram uma filha e depois de alguns anos se separaram, contudo, Norma ficou com a posse do terreno, que originalmente pertencia à família de seu marido.

Norma preservou a tradicional cobertura de palha em sua casa e o terreno que habita possui uma lagoa intermitente, que em períodos de chuva (entre janeiro e junho) enche-se de água e fornece peixe para o consumo familiar. Minha interlocutora também cria animais como pato e galinha, tem um cão como vigia e planta banana e acerola, além de cultivar plantas ornamentais e medicinais. Percebe-se que o terreno de Norma não é apenas uma residência, no sentido estrito dessa palavra, mas também um lugar de cultivo de plantas e criação de animais, o que o configura como "sítio". O terreno é cercado com estacas de madeira transpassadas por arame farpado, modelo convencional das cercas na Pedra do Sal. A família de Norma é composta por ela e sua filha, sendo, assim, monoparental. Seus vizinhos não são parentes nem dela nem de seu ex-marido.

Em agosto de 2019, a interlocutora relatou uma situação envolvendo sua vizinha. Norma chegou em casa e viu uma pessoa colocando cerca em parte de seu "terreno". Ela, então, caminhou até a pessoa e disse que aquilo não estava "certo", que o terreno era dela e não deveria ter outra cerca ali. Essa pessoa era o filho de sua vizinha, que havia retornado à Pedra do Sal para morar e constituir família. A vizinha de Norma havia possuído bons terrenos, mas os vendeu a ponto de, naquele ano, apenas lhe restar o terreno em que se localizava a sua casa. $O$ que tem acorrido na Pedra do Sal é que, ao "venderem" terreno, algumas famílias comprometeram o retorno e a permanência de seus filhos no lugar, promovendo, assim, uma tendência à migração entre as novas gerações.

Esta situação ilustra como a nova dinâmica territorial promovida com a comercialização do "terreno" afetou o arranjo familiar local e as relações vicinais, criando tensão entre vizinhos em torno de limites espaciais. Em 2016, a própria Norma já havia relatado a situação em que se encontrava sua vizinha. Contudo, três anos depois, a novidade era que a vizinha estava tentando usar o "terreno" de Norma para solucionar o problema da falta de espaço para seu filho. Durante a conversa em que a interlocutora me contou o ocorrido, ela enfatizou que se a vizinha quisesse ter o filho morando novamente no lugar, deveria não ter vendido o terreno.

Há algum tempo, Norma fazia planos de dividir aquele espaço com sua única filha, que naquele ano havia se graduado na universidade e tinha começado a trabalhar no município vizinho de Ilha Grande do Piauí. De tal forma que, se ela cedesse parte do terreno para o filho da vizinha, ela estava a comprometer a permanência da própria filha no povoado. $\mathrm{O}$ caso também ilustra o funcionamento da territorialidade pedral (MAURÍCIO, 2020), pois se a "terra" é de uso comum, o "terreno" não é compreendido dessa forma, restringindo-se a sua apropriação à família. A tentativa de se utilizar de um terreno que não é o seu é moralmente condenável, pois viola o domínio espacial familiar, socialmente reconhecido pela colocação da cerca.

A situação 1, configurada pela tentativa da vizinha de tomar parte do terreno de Norma - pois sem espaço para reestabelecer o filho no povoado -, e o fato de Norma possuir um terreno que originalmente era da família de seu marido ilustram aspectos relevantes das relações vicinais, familiares e comerciais em torno do "terreno": a) é possível a transmissão da posse do terreno entre parentes por afinidade (marido e esposa) e não apenas entre parentes consanguíneos (pai e filho); b) a situação ideal é a transmissão hereditária, isto é, de pai para filho, de 
filho para neto; c) um vizinho não pode interferir no "terreno" de outro, deve reconhecer o limite espacial sinalizado pela cerca e arcar com as consequências da venda do terreno para "gente de fora"; d) a especulação imobiliária promovida pela instalação das empresas de energia e turismo inaugurou uma outra maneira de transmitir a posse do terreno, não mais organizada pelas relações de parentesco, mas por relações comerciais, originando um mercado de "terrenos".

\section{Situação 2 - Reservar ou doar terreno}

A segunda situação que apresento envolve amigos e descreve como as relações amicais podem ser utilizadas para adentrar o terreno, mas que para a manutenção da integridade familiar desse espaço é necessário que as relações de parentesco se sobreponham às relações amicais. A situação relatada ocorreu entre Ribamar e o amigo da família, Eduardo. Ribamar fora pescador e estava como comerciante quando o conheci, em 2016. Ele mudou-se para a Pedra do Sal nos anos 1980, vindo de um povoado vizinho, o Cal. Estavam junto a ele a esposa e seis filhos. Naquela época, uma família de políticos e empresários de Parnaíba se autodeclarava a "dona" da Pedra do Sal, como já comentado, e controlava o acesso de pessoas e a construção de casas no lugar. Para Ribamar se estabelecer no povoado, ele teve que "pedir a morada" a um dos chefes daquela família.

O pedido de Ribamar foi atendido mediante sua fidelidade aos "donos" da Pedra do Sal em pleitos eleitorais da política piauiense. Após essa troca de fidelidade eleitoral por acesso à terra, Ribamar construiu sua casa e demarcou seu "terreno", contudo, sem o uso de cercas, visto terem seu uso proibido pela família Silva. Aquele era um período anterior à especulação imobiliária iniciada nos anos 2000, com poucos habitantes na Pedra do Sal, além das famílias dos primeiros ocupantes do lugar. Assim, Ribamar pôde escolher uma localização próxima à faixa de praia, que se tornaria o alvo da especulação imobiliária nas décadas seguintes. Quando conheci Eduardo na casa de Ribamar, ele era instrutor de surfe e guia para os praticantes de esportes radicais no lugar. Ele também trabalhou para uma ONG ambientalista, mas não tinha um emprego fixo e estava morando em Parnaíba com sua vó e irmã, porém visitava semanalmente a Pedra do Sal.

Em vinte e três de outubro de 2016, passei parte do dia na casa de Ribamar e presenciei a conversa entre ele e Eduardo. Era comum encontrar este na casa, pois desde a adolescência se tornara amigo da família e chegava a dormir e fazer refeições por lá. Selecionei um trecho do diário de campo, no qual descrevo esta mencionada conversa, na qual Eduardo "pediu" a Ribamar um "terreno" para construir sua casa e, assim, estabelecer-se na Pedra do Sal. O trecho apresenta como a inserção do amigo no "terreno" é percebida como uma ameaça à reserva familiar de espaço para as futuras gerações e como algo que pode trazer perturbação ao estado de "sossego", valorizado por Ribamar. A presença do amigo no terreno seria, assim, poluidora das relações que organizam o terreno como um espaço exclusivo dos parentes.

Hoje, Eduardo veio falar com seu Ribamar sobre um terreno para ele construir uma casa. Este terreno pertence a Ribamar e localiza-se próximo à casa de uma de suas filhas, em frente à casa do próprio Ribamar. Essa foi uma conversa moral, sobre ir "atrás das coisas", para não "ficar velho" e "sem nada". Eduardo falou que nunca quis luxo. Disse que se alguém quisesse luxo, teria que estudar muito, como esse rapaz, referindo-se a mim. Falou dos problemas que tinha na casa da avó, com uma de suas irmãs.

Ribamar falou que à época em que chegou na Pedral, aconselhou Eduardo a "pegar um terreno", mas ele não pegou. "Hoje tá cheio, tá difícil”, afirmou Ribamar, em tom 
de desânimo, para Eduardo. "E quanto mais o tempo passa, mais difícil fica”, concluiu, em tom igualmente pessimista. Ribamar falou que não sabe como construiu a casa na qual reside com a mulher e um dos filhos, casa esta que já abrigou os outros cinco filhos do casal. "Na época, eu era homem", ele usou essa expressão para se referir ao período em que pescava e fazia serviço de pedreiro.

Eduardo é surfista, trabalhou em serviços ambientais e parece que faz algum dinheiro com o surfe. Mora em Parnaíba. Diante do que foi colocado por Ribamar, Eduardo disse que ia "virar andarilho, hippie". Seu Ribamar não achava isso "bonito" e o reprovou por tal pensamento.

Após Eduardo ir embora, Ribamar me contou que não podia "dar o terreno", pois tudo o que havia conquistado na Pedra do Sal, vindo de um outro povoado, há mais de trinta anos, seria de seus filhos. Perguntei se não existia a possibilidade de Eduardo conseguir um "terreno" para cercar em outro lugar que não fosse ali, próximo à praia, que é onde Ribamar mora. Ele disse que Eduardo não queria "terreno lá atrás", referindo-se à área da Pedra do Sal distante da praia, mas um "terreno na frente", perto da praia, que é "onde todo mundo quer", afirmou Ribamar.

Naquele mesmo dia, Ribamar perguntou a seus filhos se Eduardo não havia conversado com eles sobre "pedir um terreno" para morar na praia. Ribamar se mostrou desconfiado com o "pedido" de Eduardo e temeroso com uma possível decisão favorável dos filhos em ceder alguma parte de seus terrenos ao amigo.

\begin{abstract}
Ribamar disse que ninguém sabia se, depois de construída a casa em frente a de Ribamar ou ao lado da casa de seus filhos, Eduardo não a venderia e lá se instalaria uma "pessoa ruim", que iria tirar o "sossego da família". Ribamar até desconfiou que existia alguém por trás do "pedido" de Eduardo e que tudo isso poderia ser um "esquema" premeditado para ele "ganhar um terreno" e depois vendê-lo.

Naquele dia, Ribamar também lembrou que, certa vez, pediu aos filhos para venderem parte de um terreno deles, como uma forma de ajudar Ribamar a ter o dinheiro suficiente para comprar um carro. Contudo, os filhos não levaram adiante a proposta do pai e ninguém na família falou novamente em "vender terreno". Em conversa com os filhos, Ribamar disse que ficaria "chateado" se eles, depois de terem negado vender um terreno para "ajudar o pai", dessem um terreno para "ajudar um colega". Ribamar, então, alertou a uma de suas filhas que, quando o seu próprio filho crescesse, também ia precisar de um lugar pra morar e, se ela desse parte do terreno para Eduardo, comprometeria o futuro do filho e dela mesma, pois teria que "se espremer" com o filho casado numa mesma casa. (Diário de campo, 23 de outubro de 2016).
\end{abstract}

A situação relatada acima, a envolver o pai, os filhos e o amigo, trata das consequências da transmissão da posse do terreno, se ele deveria ir para um amigo ou permanecer entre parentes. Essas opções são pensadas por Ribamar como tendo possíveis consequências: a) a doação do terreno para Eduardo poderia tirar o "sossego" da família, pois o amigo, em posse de parcela do terreno, poderia vendê-lo a um "estranho", não tendo mais a família o controle sobre quem estaria nas proximidades das casas; b) uma outra consequência da doação a Eduardo seria o comprometimento de terrenos disponíveis para a terceira geração da família de Ribamar, no caso, o seu neto; c) por outro lado, a permanência dos terrenos em posse dos membros da família preservaria o "sossego" do lugar e garantiria aos netos de Ribamar o acesso ao terreno no futuro; d) a atitude de Ribamar em alertar aos filhos sobre as possibilidades negativas da doação a Eduardo indica que, ao transferir o terreno ao filho, o pai também delega a autoridade sobre aquele pedaço da posse familiar a quem o recebeu, não cabendo ao patriarca decisões sobre venda ou doação do terreno de um filho, apenas o aconselhamento sobre o que fazer com a posse; e) a amizade construída ao logo do tempo entre a família de Ribamar e Eduardo não foi suficiente para romper a divisa simbólica que o parentesco estabelece no terreno. A amizade não foi capaz de trazer para o interior do terreno um não-parente3.

\footnotetext{
3 Existe uma questão em aberto sobre a qual não disponho de dados etnográficos suficientes para respondê-la. O que aconteceria se um amigo comprasse o "terreno"? Qual seria a reação dos parentes, por exemplo, se, ao invés de Eduardo pedir a Ribamar e a seus filhos, ele houvesse proposto comprar o terreno? Eles venderiam ou preservariam a posse para a próxima geração? Nesta situação imaginada, identifico dois possíveis desdobramentos: a) a venda a Eduardo diminuiria a reserva de terreno para a próxima geração, expondo esta à migração; b) monetizaria as relações de Eduardo com a família de Ribamar, reconfigurando a relação amical numa relação comercial e, em seguida, numa relação de vizinhança.
} 
A argumentação anteriormente empregada por Norma para não ceder parte de seu terreno à vizinha foi a mesma utilizada por Ribamar para alertar sua filha a não ceder "terreno" ao amigo Eduardo. Fazer a posse do terreno circular entre parentes, evitando a inclusão de amigos e vizinhos em seus limites, é uma forma de ofertar alguma segurança territorial aos filhos e netos e, assim, garantir a reprodução social espacialmente orientada da família. Como descrito anteriormente, o casamento de um membro da família é o momento em que o filho recebe do pai parte do "terreno". Assim, o casamento não é apenas o ritual de passagem do solteiro para a condição de casado, é também a passagem do não possuidor para a condição de possuidor de terreno.

Se a Situação 1 ajuda a compreender a natureza familiar do terreno a partir da relação entre vizinhos, a Situação 2 auxilia o entendimento da natureza familiar do terreno a partir da relação entre amigos. Os casos de Norma e Ribamar ilustram que o terreno é um espaço organizado a partir do parentesco a ponto de a presença do amigo ou vizinho ser percebida como elemento "poluidor", pois, não-familiar. Assim, a presença de um não-parente tende a ser encarada como algo que pode causar instabilidade naquele espaço, que é concebido como em estado de "sossego" à medida que se mantém como um microterritório de parentes. Na Situação 1, a cerca ganhou destaque como aquilo que emoldurou (SIMMEL, 2013) o terreno de Norma em relação ao de sua vizinha, sendo o uso da cerca uma forma de produzir "terreno" a partir de divisão do espaço. O caso de Ribamar revela como não é apenas a cerca, mas também o parentesco um produtor de terreno ao reforçar a divisão simbólica entre parentes e amigos.

A realização de doação (Situação 2) ou venda (Situação 1) do terreno o desfaz como espaço exclusivamente familiar, podemos dizer, o "desfamiliariza", pois retira-o da esfera de circulação entre as gerações de parentes e o põe numa circulação mais ampla, na qual o terreno poderá circular entre amigos e vizinhos, rompendo a lógica da sucessão hereditária na transmissão da posse. Assim, o fracionamento do terreno pode assumir uma estratégia intrafamiliar através da sucessão hereditária, restringindo a sua circulação aos parentes, ou extrafamiliar, repassando-o a não-parente mediante a venda, como ocorreu com a vizinha de Norma.

\section{Situação 3 - Tomar e retomar terreno}

Foi descrito na Situação 2 como o pedido de "terreno" por amigo produziu anseios em torno da perda de "sossego" e de espaço para as próximas gerações da família. Na Situação 3, será apresentada a tentativa de um amigo de apropriar-se de terreno sem o consentimento da família e como os parentes retomaram a posse. O trecho a seguir é do diário de campo e relata o que Naldo, filho de Ribamar, contou-me dias depois daquela visita de Eduardo à casa da família. Por alguns dias, o assunto do pedido de Eduardo ainda rondou as conversas na casa e reavivou memórias sobre o terreno.

Naldo lembrou de um caso que o seu pai, Ribamar, já havia me adiantado. Ele falou que um homem, dono de loja de construção e residente em Parnaíba, foi se aproximando da família e fazendo amizade com seu pai. Este homem vinha à casa de Ribamar e, certa vez, disse que gostaria de construir uma casa perto da dele, porque eles eram amigos. Seu Ribamar disse que não dava, pois o terreno próximo à casa estava destinado a seu filho e, se cedesse, prejudicaria o próprio filho. O homem disse que iria ajudar os filhos de Ribamar e que isso não seria problema.

Dessa maneira, o estabelecimento do nexo monetário desencadearia a transformação de Eduardo (de amigo à comprador) e o reposicionaria socioespacialmente em relação à família de Ribamar (de amigo a vizinho). 


\begin{abstract}
Certo dia, o homem veio com trabalhadores em um caminhão e colocou estacas no terreno de Ribamar. Essas estacas eram uma forma de marcar o terreno para uma futura construção. Nesse mesmo dia, à noite, Naldo e alguns amigos foram até o terreno e tiraram aquelas estacas. Naldo me disse que foi bastante cuidadoso com as estacas, que colocou tudo num determinado lugar, que não as quebrou nem as levou para si.

Os dias passaram e o homem voltou para ver o terreno que ele já considerava como seu, mas se surpreendeu. As estacas que havia colocado, não estavam mais ali. Indignado, foi até a casa de Ribamar e disse que teria prejuízo com o material, com a mão de obra e com ofrete que gastou ao transportar os materiais e os trabalhadores para a Pedra do Sal. Houve uma discussão entre Ribamar e este homem. Ele ameaçou colocar Ribamar na justiça, mas não deu em nada. Depois daquele dia, o homem não mais incomodou a família. (Diário de campo, 26 de outubro de 2016)
\end{abstract}

O caso acima ilustra, mais uma vez, a natureza do terreno como um espaço iminentemente familiar cujo domínio e controle pertencem aos parentes. A amizade, seja a que Eduardo estabeleceu ao longo de vários anos com a família de Ribamar, seja aquela que o parnaibano tinha iniciado há pouco tempo, não foi uma condição que possibilitou a circulação extrafamiliar da posse do terreno. Em nenhum dos casos, ser amigo da família foi condição favorável para possuir um dos terrenos.

Pode-se inferir da Situação 3 alguns elementos da micropolítica do terreno na Pedra do Sal: a) a ação invasiva do parnaibano, ao colocar as estacas no futuro terreno de Naldo, teve uma rápida resposta da família, que, aliada a alguns verdadeiros amigos, retirou as estacas, destituindo o parnaibano da posse do terreno e, por sua vez, restituindo a posse familiar, isso quer dizer, refamiliarizando o terreno4; b) uma maneira legitimamente reconhecida da "gente de fora" possuir o "terreno" de uma família é mediante a compra e não a tomada de terreno; c) é possível uma família vender e reservar terreno, pois o próprio Ribamar havia, anos atrás, loteado e vendido algumas extensões de sua posse, mas, diferente da vizinha de Norma, assegurou-se de que essa diminuição do terreno não comprometeria a permanência dos filhos nas imediações da casa do pai e, por conseguinte, no povoado. De tal maneira que, cerca de trinta anos após chegar à Pedra do Sal, os filhos de Ribamar habitam em terrenos da família, com exceção de um, que não se casou e mora com os pais.

\title{
Família, espaço e reprodução social na Pedra do Sal
}

No estudo Herdeiros, parentes e compadres, Ellen Woortmann (1995) analisou a relação entre parentesco e herança da terra entre famílias de colonos do Sul e entre famílias de sitiantes do Nordeste. Sua análise destacou a relevância do patrimônio e dos padrões de herança para a compreensão da reprodução social do campesinato, oferecendo uma perspectiva diferente daquela baseada exclusivamente no trabalho, como na acepção chayanoviana do ciclo de desenvolvimento da família. Em Como uma família: sociabilidade, territórios de parentesco e sindicalismo rural, John Cunha Comerford (2003) identificou, na Zona da Mata de Minas Gerais, o que ele nomeou de territórios de parentesco, entendidos como a expressão e consolidação territorial de um estado de relações entre famílias. $\mathrm{O}$ autor argumentou que a ação em torno de divisas ia formando "um padrão de territórios de parentesco, que concentravam residências e/ou locais de trabalho de parentes reconhecidos e valorizados como tais, bem como compadres e comadres" (COMERFORD, 2003: 40).

4 Atente o leitor que o caso ocorreu sem a participação de agentes do poder judiciário, sem a mediação do código jurídico da sociedade nacional e foi resolvido pela própria família como uma "questão de família", envolvendo no ocorrido apenas os parentes e os amigos próximos. 
Em Os deserdados da terra, Margarida Maria Moura (1978) descreveu como um código consuetudinário pode sobrepor-se ao Código Civil brasileiro na transmissão da posse da terra via herança familiar entre camponeses do Vale do Jequitinhonha, em Minas Gerais. Para a autora, na herança está "incrustado um aspecto crucial da reprodução da área como camponesa: a reposição da terra para a geração jovem, condição sine qua non para a aquisição da condição camponesa" (MOURA, 1978: 2).

No estudo O trabalho da memória: cotidiano e história no sertão do Piauí, Emília Godói (1999) buscou compreender como os camponeses do sudeste piauiense pensavam e viviam sua relação com a terra e quais eram os direitos que ordenavam aquela relação. A autora teve como objeto de análise a mudança para a posse privada de uma terra que por 122 anos foi de uso comum daqueles que se entendiam como descendentes do mesmo tronco, o do Véio Vitorino. A partir das noções thompsoniana de economia moral e bourdieusina de habitus, orientada ainda pelo imbricamento entre evento e estrutura, tal como professado na perspectiva sahlinsiana, a autora concluiu que as mudanças advindas com a demarcação e titulação da terra, ao invés de desarticularem uma tradição de uso e sucessão, foram elementos de atualização de uma ética tradicional relativa à posse comum da terra e que aqueles camponeses souberam articular a transformação do ordenamento jurídico da terra com a reprodução de sua tradição de ocupação e uso.

A partir da moderna literatura da antropologia rural brasileira, o leitor pode constatar que não constitui novidade alguma o estudo da relação entre aspectos da espacialidade e da reprodução social da família rural. Contudo, a análise da relação entre reprodução social, padrões de herança e espaço a partir do caso da Pedra do Sal traz algumas dificuldades ao pesquisador que tentar encaixá-lo nos diagramas das teorias recorrentes. A primeira dificuldade reside na plasticidade das relações de propriedade naquele povoado. Essas relações foram alteradas ao longo do tempo, tendo experimentado as famílias daquela parte rochosa do litoral piauiense pelo menos três regimes de propriedade: o primeiro foi aquele anterior à chegada da família Silva, no qual o morador detinha a posse do "terreno" e fazia uso livre da "terra"; o segundo inaugura-se com o mandonismo silvista, por volta do início do século XX, no qual o morador continuou a usar livremente a "terra", mas os Silva regulavam a ocupação do "terreno" proibindo o uso de cerca; o terceiro constituiu-se após o fim da relação de morada, a partir dos anos 2000, no qual o morador passou a ter a posse do "terreno" e a utilizar a cerca como demarcadora de espaço familiar, mas o uso livre da "terra" foi comprometido pelo impacto ambiental promovido pelas empresas de energia eólica e turismo imobiliário.

Nesse sentido, não houve um modelo, pelo menos não tão estável, como aqueles encontrados na "maison francesa, na stem family irlandesa e na Stammhaus dos colonos teuto brasileiros" (WOORTMANN, 2001: 11), que conservaram, ao longo do tempo, certas regras socialmente reconhecidas de ocupação da terra e transmissão da propriedade familiar. Nesse sentido, optei por trabalhar os dados do campo de pesquisa a partir da ideia de micropolítica do terreno, pois permitiu-me visualizar um conjunto de estratégias (a prática) operadas pelas famílias e articulá-las a um conjunto de regras (a estrutura) em mutação no que se refere à posse do terreno e sua transmissão.

Pode-se identificar dois tipos mais regulares de transmissão da posse entre as famílias pedral no contexto da escassez de terrenos: a transmissão via sucessão hereditária e via troca monetária. A primeira ocorre quando o pai transfere ao 
filho uma parcela do terreno após o casamento. O filho constrói uma casa nas imediações da casa do pai, iniciando uma outra família conjugal, de modo que o terreno se torna o espaço de uma família extensa. O filho passa a ser a autoridade sobre aquela parcela de terreno onde habita. O pai torna-se um conselheiro sobre o que fazer com o terreno, mas não é mais o "dono". Caso surja a necessidade de vender parcela do terreno, isso é debatido entre pais e filhos.

O segundo tipo de transmissão é através da troca monetária. Nela, o terreno é vendido para um não-parente, isto é, "gente de fora" do povoado ou, em casos menos comuns, a um morador do lugar sem vínculo de parentesco. Diferente da sucessão hereditária, na qual o terreno é um patrimônio familiar, ele se torna uma mercadoria na troca monetária, possuindo um valor de troca e não apenas um valor de uso. Os dois tipos de transmissão do terreno ocorrem sem a mediação do código jurídico da sociedade nacional, pois os nativos do lugar não possuem título de propriedade. Assim, o terreno como patrimônio ou como mercadoria circula na Pedra do Sal através de acordos firmados verbalmente entre as partes, seja pai e filho, seja vendedor e comprador. Observa-se, então, como as estratégias de transmissão se sobrepõem às regras do Código Civil no que concerne à jurisdição da posse dos terrenos entre familiares e não-familiares.

A transmissão do terreno via troca monetária está criando as condições objetivas, isto é, a falta de espaço físico, para transformações na estrutura da família pedral. O filho de morador que migrou para outra cidade em busca de emprego já não consegue se reestabelecer no lugar como antes, pois falta-lhe terreno para construir casa e iniciar sua própria família conjugal. A "gente de fora" tem adquirido terrenos próximos à faixa de praia, o que tem deslocado o morador "para trás", interiorizando-o na geografia do povoado e restando-lhe os terrenos desvalorizados culturalmente e economicamente, pois distantes da praia. É nesse contexto particular de escassez que operará a micropolítica do terreno a partir da reserva ou venda, tomada ou retomada de espaço.

Nesse sentido, percebe-se como a comercialização do patrimônio familiar assenta as condições para uma crise na reprodução social da família pedral, que passou a encontrar dificuldades em reterritorializar os parentes que haviam migrado. Desse modo, reservar o terreno, isto é, não o vender, é uma estratégia que permite a reprodução social da família de modo espacialmente orientado ou, em outras palavras, garante uma territorialização do parentesco de modo que uma configuração espacial, o "terreno", corresponda a uma estrutura social, a família.

Outra dimensão importante para a compreensão do "terreno" na Pedra do Sal, é o fato da sua transmissão hereditária não envolver uma monetização dos vínculos entre o ascendente e o seu descendente. Essa transmissão obedece a uma lógica sucessória, baseada na hereditariedade, e diferencia-se da troca monetária ordenada pela venda e compra. De tal maneira que as lógicas que organizam a fragmentação do terreno familiar são diferentes nas relações entre parentes (sucessão hereditária) e nas relações entre não-parentes (troca monetizada).

A espacialização da família no terreno envolve divisas espaciais socialmente produzidas e reconhecidas como tais, a indicar a existência daquilo que Simmel (2013) nomeou de centripetalidade sociológica de uma unidade interativa, que se expressa no espaço através de um limite que a emoldura. Em outras palavras, o sociólogo alemão chama atenção sobre como determinada interação social pode se concentrar em um espaço físico delimitado por essa própria interação, de tal maneira que uma ordem social sustenta uma configuração espacial e vice versa.

Para Simmel (2013: 79), 
uma qualidade do espaço que opera de modo crucial sobre as interações sociais reside no fato de que o espaço se decompõe, para o nosso aproveitamento prático, em pedaços que valem como unidades [...] e que são emoldurados por limites.

Alguns anos após Simmel escrever essas linhas em 1903, Durkheim ([1912] 1978) dedicou uma reflexão sobre o espaço num trecho pouco comentado de As formas elementares da vida religiosa. Contrapondo-se ao kantismo, ele afirma que o espaço não é um meio vago e indeterminado. O sociólogo francês compreende que o espaço se torna propriamente espaço pela mediação das representações sociais que o dividem e o diferenciam. Estas, continua ele, originam-se de diferentes valores afetivos atribuídos às regiões. Para Durkheim, o espaço, assim como o tempo, torna-se compreensivo e socialmente manejável se dividido e diferenciado a partir de determinados valores atribuído a ele pelo grupo social, não sendo um dado a priori, possuindo variações entre as sociedades.

Na Pedra do Sal, o "terreno" pode ser compreendido como uma unidade emoldurada por limites, no sentido simmeliano, seja o limite físico posto pela cerca, seja o limite simbólico entre parentes e não-parentes organizado pelo parentesco. Já num sentido durkheimiano, o "terreno" é esse espaço que não se confunde com a "terra" e é produto das operações de divisão e diferenciação dos moradores do lugar, que atribuem valor e uso comunitário à "terra" e valor e uso familiar ao "terreno".

O uso comum da "terra" na Pedra do Sal indica a existência de um princípio de abertura como ordenador desse tipo de uso, pois é legítimo que qualquer morador possa utilizar-se de uma mata, lagoa ou mangue. Contudo, a posse familiar do "terreno" expressa um princípio de fechamento como organizador dessa posse, pois apenas parentes têm legitimidade de o manejarem. A depender do estatuto da pessoa, ela estará habilitada a utilizar determinado espaço. Se é um espaço percebido como "terra" e, assim, de uso comum, a condição de morador é suficiente para um uso legitimado. Contudo, se é um espaço percebido como "terreno" e, por sua vez, de uso familiar, somente a condição de parente outorga legitimidade à apropriação.

O fechamento do terreno em relação a não-parentes, tanto em seu aspecto material (cerca) como simbólico (parentesco), ordena a reserva de terreno para a próxima geração e, assim, organiza uma reprodução social espacialmente orientada. Tomar o terreno de uma família ou tentar adentrá-lo com outra cerca são práticas que desafiam o princípio de fechamento. Nesse contexto, a cerca ganha relevância como dispositivo que afirma uma divisa espacial, emoldurando fisicamente o espaço, e o parentesco é reforçado como aquilo que cerca simbolicamente o terreno. A violação da cerca operada por vizinho (Situação 1) e por amigo (Situação 3) é uma violação da regra de parentesco que ordena aquele espaço como microterritório de parentes. A família tem recorrido à cerca e ao parentesco para fazer funcionar o princípio de fechamento do terreno para vizinho e amigo e, assim, manter a configuração familiar desse espaço. O bom manejo do conflito e da solidariedade entre parente, vizinho e amigo preserva o "terreno" como espaço de reprodução social da família pedral, evitando a migração de parente e garantindo a centripetalidade sociológica da família no terreno num contexto de escassez de espaço. 
Recebido em 3 de outubro de 2020.

Aceito em 19 de dezembro de 2020.

\section{Referências}

BEZERRA, Maria Bernadete de Carvalho. Percepção socioambiental da comunidade Pedra do Sal acerca da implantação do Complexo Eólico Delta do Parnaíba na APA Delta do Parnaíba/PI. Dissertação de mestrado, Desenvolvimento e Meio Ambiente, UFPI, 2016.

BEZERRA, Maria Bernadete de Carvalho et al. Percepção dos impactos socioambientais decorrentes da implantação do complexo eólico Delta do Parnaíba. Gaia Scientia, 11 (1): 116-130, 2017.

CASTELlO BRANCO FILHO, Moysés. O povoamento do Piauí. Teresina: Comepi, 1982.

COMERFORD, John Cunha. Como uma família: sociabilidade, territórios de parentesco e sindicalismo rural. Rio de Janeiro: Relume Dumará, 2003.

COMISSÃO ILHA ATIVA. Sócio biodiversidade da Ilha Grande de Santa Isabel: Um olha da comunidade visando à RESEX do Cajuí. Ilha Grande: [s.n.], 2012.

DURKHEIM, Émile. “As formas elementares da vida religiosa”. In: GIANNOTTI, José Arthur. Émile Durkheim. São Paulo: Abril Cultural, 1978. pp. 203-245. (Coleção Os Pensadores).

ELIAS, Norbert; SCOTSON, John L. Os estabelecidos e os outsiders. Rio de Janeiro: Jorge Zahar, 2000.

GODÓI, Emília Pietrafesa de. O trabalho da memória: cotidiano e história no sertão do Piauí. Campinas: Editora da UNICAMP, 1999.

GODÓI, Emília Pietrafesa. Territorialidade: trajetória e usos do conceito. Raízes, 34 (2): 8-16, 2014.

LITTLE, Paul. Territórios sociais e povos tradicionais no Brasil: por uma antropologia da territorialidade. Série Antropologia, 322, 2002.

MARTINS, José de Souza. “Orelha”. In: MOURA, Margarida Maria. Os herdeiros da terra: parentesco e herança numa área rural. São Paulo: Hucitec, 1978.

MAURÍCIO, Francisco Raphael Cruz. Os filhos do lugar: crônicas da territorialidade pedral. Tese de doutorado, Sociologia, UFC, 2020.

MAUSS, Marcel. Manual de etnografia. Lisboa: Editorial Pórtico, 1972.

MOURA, Margarida Maria. Os herdeiros da terra: parentesco e herança numa área rural. São Paulo, Hucitec, 1978.

SIMMEL, Georg. Sociologia do espaço. Estudos avançados, 27 (79): 75-112, 2013. VERÇOZA, Lúcio Vasconcelos de. "Expropriação e memória na região dos tabuleiros de cana”. In: SILVA, Maria Aparecida de Moraes; VERÇOZA, Lúcio Vasconcelos de. Vidas talhadas no avesso da história. São Paulo: Annablume, 2018. pp. $45^{-86 .}$ 
WOORTMANN, Ellen. Herdeiros, Parentes e Compadres. São Paulo: Hucitec/EdUnb, 1995.

WOORTMANN, Klass. O modo de produção doméstico em duas perspectivas: Chayanov e Sahlins. Série Antropologia, 293, 2001.

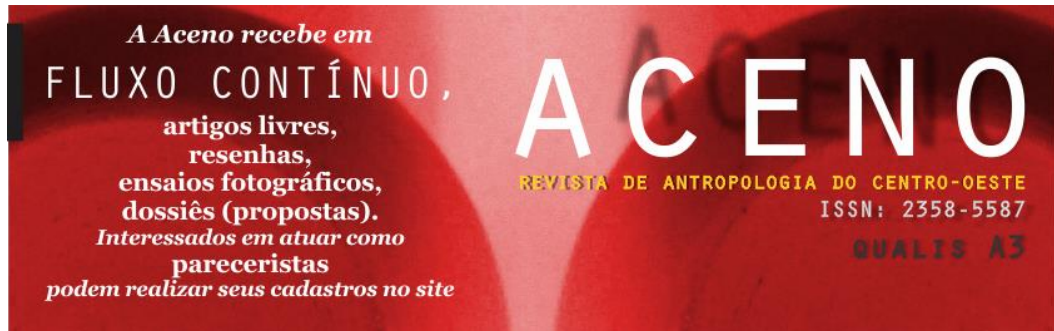

